\title{
STUDY ON MULTI-OBJECTIVE OPTIMIZATION OF THE TURNING PROCESS OF EN 10503 STEEL BY COMBINATION OF TAGUCHI METHOD AND MOORA TECHNIQUE
}

\author{
Do Duc Trung \\ Faculty of Mechanical Engineering ${ }^{l}$ \\ doductrung@haui.edu.vn \\ Nhu-Tung Nguyen \\ Faculty of Mechanical Engineering ${ }^{l}$ \\ tungnn@haui.edu.vn \\ Duong Van Duc \\ Faculty of Mechanical Engineering ${ }^{1}$ \\ duongduc67@gmail.com \\ ${ }^{1}$ Hanoi University of Industry \\ 298 Cau Dien str., Bac Tu Liem District, Hanoi, Vietnam, 100000
}

\begin{abstract}
In this study, the multi-objective optimization problem of turning process was successfully solved by a Taguchi combination method and MOORA techniques. In external turning process of EN 10503 steel, surface grinding process, the orthogonal Taguchi $L_{9}$ matrix was selected to design the experimental matrix with four input parameters namely insert nose radius, cutting velocity, feed rate, and depth of cut. The parameters that were chosen as the evaluation criteria of the machining process were the surface roughness $(R a)$, the cutting force amplitudes in $X, Y, Z$ directions, and the material removal rate (MRR). Using Taguchi method and MOORA technique, the optimized results of the cutting parameters were determined to obtain the minimum values of surface roughness and cutting force amplitudes in $X, Y, Z$ directions, and maximum value of $M R R$. These optimal values of insert nose radius, cutting velocity, feed rate, and cutting depth were $1.2 \mathrm{~mm}, 76.82 \mathrm{~m} / \mathrm{min}, 0.194 \mathrm{~mm} / \mathrm{rev}$, and $0.15 \mathrm{~mm}$, respectively. Corresponding to these optimal values of the input parameters, the surface roughness, cutting force amplitudes in $X, Y, Z$ directions, and material removal rate were $0.675 \mu \mathrm{m}, 124.969 \mathrm{~N}, 40.545 \mathrm{~N}, 164.206 \mathrm{~N}$, and $38.130 \mathrm{~mm} / \mathrm{s}$, respectively. The proposed method in this study can be applied to improve the quality and effectiveness of turning processes by improving the surface quality, reducing the cutting force amplitudes, and increasing the material removal rate. Finally, the research direction was also proposed in this study.
\end{abstract}

Keywords: Multi-Objective Optimization, Taguchi, Moora, Turning process, EN 10503 Steel.

DOI: $10.21303 / 2461-4262.2020 .001414$

\section{Introduction}

Turning is one of the most common machining processes in the cutting methods. The work volume that the lathes perform about $40 \%$ of the total workload of the machining processes, and the number of lathes accounts about $25-35 \%$ of the total number of machine tools in the cutting workshop [1].

Many studies were performed to improve the accuracy and productivity of machining processes [1-12]. In which, most studies focus on determining the optimal values of the cutting parameters to ensure the surface roughness with the smallest value, the force components with the smallest values, and the material removal rate with greatest value.

The response surface method $(R S M)$ was applied to optimize the turning process of AISI 410 [2], turning process of Inconel 718 Nickel-base super alloy [3, 4]. RSM and Genetic Algorithm $(G A)$ were also combined to optimize the turning process of AISI 1040 [5], turning process of martensitic stainless steel [6], and turning process of EN8 steel [7].

Particle swarm optimization (PSO) algorithm was applied to optimize the turning process of AISI D2 [8]. The regression analysis method was used to optimize the turning process of PM nickel-based superalloy [9]. Weighting factor method and $G A$ algorithm were applied to optimize the turning process of 52100 steel [10]. 
Taguchi method was applied to optimize the turning process with different materials such as aluminum [11], polyethylene [12], thermoplastic polymer-delrin 500 AL [13], EN 8 steel [14], aluminum 6063 [15], AISI 316L stainless steel [16], AM alloy [17], AISI 1045 steel [18], S45C steel [19], Aluminum, Brass, and Copper [20], Mild Steel [21], EN 354 steel [22], Titanium Alloy Ti-6Al-4V [23], AISI 1020 MS steel [24], Aluminium-2014 Alloy [25], AISI 409 steel [26], P20 steel [27], and so on.

A combination method of Taguchi and Grey relational analysis (GRA) was used to optimize the turning process of DIN 1.2344 steel [28], turning the unidirectional glass fiber reinforced plastic (UD-GFRP) composite rods [29], turning the EN-8, EN-31 steel and EN-36 steel [30], turning the DIN Ck45 steel [31]. Taguchi was combined to TOPSIS and SAW method to optimize the turning process of Ti-6Al-4V alloy under minimum quantity lubrication $(M Q L)$ [32]. Taguchi was also combined to GA and PSO algorithm to optimize the turning process of S45C steel [33].

The summary of the reviewed literatures about the optimization of the turning processes including the materials, the aims, the methods, and the optimized results of each study as listed in Table $\mathbf{1 .}$

Table 1

Summary of the reviewed literatures about the optimization of turning process

\begin{tabular}{|c|c|c|c|c|}
\hline Workpiece material & Aims & $\begin{array}{c}\text { Optimization } \\
\text { method/algorithms }\end{array}$ & Input values and their value & Ref. \\
\hline 1 & 2 & 3 & 4 & 5 \\
\hline AISI 410 & Minimum surface roughness & RSM & $\begin{array}{l}\text { - Cutting velocity } 255.75 \mathrm{~m} / \mathrm{min} \\
\text { - Feed rate } 0.1 \mathrm{~mm} / \mathrm{rev} \\
\text { - Depth of cut } 0.3 \mathrm{~mm} \\
\text { - Tool nose radius } 1.2 \mathrm{~mm}\end{array}$ & [2] \\
\hline $\begin{array}{l}\text { Inconel } 718 \text { Nickel- } \\
\text { base super alloy }\end{array}$ & Minimum surface roughness & RSM & $\begin{array}{l}\text { - Cutting velocity } 70 \mathrm{~m} / \mathrm{min} \\
\text { - Feed rate } 0.09 \mathrm{~mm} / \mathrm{rev} \\
\text { - Tool nose radius } 0.4 \mathrm{~mm}\end{array}$ & [3] \\
\hline $\begin{array}{l}\text { Inconel } 718 \text { Nickel- } \\
\text { base super alloy }\end{array}$ & $\begin{array}{l}\text { - Minimum surface roughness; } \\
\text { - Minimum cutting force; } \\
\text { - Minimum power; } \\
\text { - Maximum tool life; } \\
\text { - Maximum MRR }\end{array}$ & RSM & $\begin{array}{l}\text { - Cutting velocity } 40 \mathrm{~m} / \mathrm{min} \\
\text { - Feed rate } 0.1 \mathrm{~mm} / \mathrm{rev} \\
\text { - Depth of cut } 1.0 \mathrm{~mm}\end{array}$ & [4] \\
\hline AISI 1040 steel & Minimum main cutting force $\left(P_{z}\right)$ & $\mathrm{RSM}+\mathrm{GA}$ & $\begin{array}{l}\text { - Cutting velocity } 142.284 \mathrm{~m} / \mathrm{min} \text {; } \\
\text { - Feed rate } 0.029 \mathrm{~mm} / \mathrm{rev}\end{array}$ & [5] \\
\hline $\begin{array}{l}\text { Martensitic stainless } \\
\text { steel }\end{array}$ & Minimum surface roughness & $\mathrm{RSM}+\mathrm{GA}$ & $\begin{array}{l}\text { - Cutting velocity } 119.93 \mathrm{~m} / \mathrm{min} \text {; } \\
\text { - Feed rate } 0.15 \mathrm{~m} / \mathrm{min} \\
\text { - Depth of cut } 0.5 \mathrm{~mm}\end{array}$ & [6] \\
\hline EN28 steel & Minimum surface roughness & $\mathrm{RSM}+\mathrm{GA}$ & $\begin{array}{l}\text { - Workpiece speed } 800 \mathrm{rpm} \\
\text { - Feed rate } 0.3 \mathrm{~m} / \mathrm{min} \\
\text { - Depth of cut } 0.3 \mathrm{~mm}\end{array}$ & [7] \\
\hline AISI D2 steel & $\begin{array}{l}\text { - Minimum surface roughness; } \\
\text { - Minimum tool wear }\end{array}$ & PSO & $\begin{array}{l}\text { - Cutting velocity } 67.5 \mathrm{~m} / \mathrm{min} \\
\text { - Feed rate } 0.0425 \mathrm{~mm} / \mathrm{rev}\end{array}$ & {$[8]$} \\
\hline $\begin{array}{l}\text { PM nickel-based } \\
\text { superalloy }\end{array}$ & Minimum cutting force & $\begin{array}{l}\text { Regression } \\
\text { analysis }\end{array}$ & $\begin{array}{l}\text { - Cutting velocity } 20 \div 40 \mathrm{~m} / \mathrm{min} \text {; } \\
\text { - Feed rate } 0.08 \div 0.1 \mathrm{~mm} / \mathrm{rev} \text {; } \\
\text { - Depth of cut } 0.1 \div 0.15\end{array}$ & [9] \\
\hline \multirow[t]{4}{*}{52100 steel } & Minimum surface roughness & $\begin{array}{l}\text { Weighting } \\
\text { factors }+G A\end{array}$ & $\begin{array}{l}\text { - Cutting velocity } 100 \div 300 \mathrm{~m} / \mathrm{min} \text {; } \\
\text { - Feed rate } 0.15 \mathrm{~mm} / \mathrm{rev} \\
\text { - Depth of cut } 1.0 \mathrm{~mm}\end{array}$ & {$[10]$} \\
\hline & Minimum power & & $\begin{array}{l}\text { - Cutting velocity } 100 \mathrm{~m} / \mathrm{min} \\
\text { - Feed rate } 0.15 \mathrm{~mm} / \mathrm{rev} \\
\text { - Depth of cut } 1.0 \mathrm{~mm}\end{array}$ & \\
\hline & Minimum cutting times & & $\begin{array}{l}\text { - Cutting velocity } 300 \mathrm{~m} / \mathrm{min} \text {; } \\
\text { - Feed rate } 0.45 \mathrm{~mm} / \mathrm{rev} \\
\text { - Depth of cut } 1.0 \mathrm{~mm}\end{array}$ & \\
\hline & Minimum cutting force $\left(F_{z}\right)$ & & $\begin{array}{l}\text { - Cutting velocity } 300 \mathrm{~m} / \mathrm{min} \text {; } \\
\text { - Feed rate } 0.15 \mathrm{~mm} / \mathrm{rev} \\
\text { - Depth of cut } 1.0 \mathrm{~mm}\end{array}$ & \\
\hline
\end{tabular}




\section{Continuation of Table 1}

\begin{tabular}{|c|c|c|c|c|}
\hline 1 & 2 & 3 & 4 & 5 \\
\hline Aluminum & Minimum surface roughness & Taguchi & $\begin{array}{l}\text { - Cutting velocity } 35 \mathrm{~m} / \mathrm{min} \text {; } \\
\text { - Feed rate } 0.15 \mathrm{~mm} / \mathrm{rev} ; \\
\text { - Depth of cut } 1.25 \mathrm{~mm}\end{array}$ & {$[11]$} \\
\hline Polyethylen e & Minimum surface roughness & Taguchi & $\begin{array}{l}\text { - Cutting velocity } 213.88 \mathrm{~m} / \mathrm{min} \text {; } \\
\text { - Feed rate } 0.049 \mathrm{~mm} / \mathrm{rev} \text {; } \\
\text { - Depth of cut } 2.0 \mathrm{~mm} \text {; } \\
\text { - Tool nose radius } 0.8 \mathrm{~mm}\end{array}$ & [12] \\
\hline \multirow[t]{2}{*}{$\begin{array}{l}\text { Thermoplastic } \\
\text { polymer-delrin } \\
\text { 500AL }\end{array}$} & Minimum surface roughness & Taguchi & $\begin{array}{l}\text { - Workpiece speed } 250 \mathrm{rpm} ; \\
\text { - Feed rate } 0.15 \mathrm{~mm} / \mathrm{rev} \\
\text { - Depth of cut } 0.14 \mathrm{~mm}\end{array}$ & [13] \\
\hline & Maximum MRR & & $\begin{array}{l}\text { - Workpiece speed } 300 \mathrm{rpm} ; \\
\text { - Feed rate } 0.25 \mathrm{~mm} / \mathrm{rev} \\
\text { - Depth of cut } 0.14 \mathrm{~mm}\end{array}$ & \\
\hline EN8 steel & Minimum surface roughness & Taguchi & $\begin{array}{l}\text { - Workpiece speed } 303 \mathrm{rpm} \text {; } \\
\text { - Feed rate } 0.067 \mathrm{~mm} / \mathrm{rev} \\
\text { - Depth of cut } 0.2 \mathrm{~mm}\end{array}$ & [14] \\
\hline Aluminum 6063 & Minimum power & Taguchi & $\begin{array}{l}\text { - Workpiece speed } 1750 \mathrm{rpm} \\
\text { - Feed rate } 0.3 \mathrm{~mm} / \mathrm{rev} \\
\text { - Depth of cut } 1.2 \mathrm{~mm}\end{array}$ & [15] \\
\hline $\begin{array}{l}\text { AISI 316L stainless } \\
\text { steel }\end{array}$ & $\begin{array}{l}\text { - Minimum surface roughness; } \\
\text { - Minimum cutting force }\end{array}$ & Taguchi & $\begin{array}{l}\text { - Increasing the feed rateand depthofcut, } \\
\text { the surface roughness and cutting forces } \\
\text { increased. } \\
\text { - When using MQL, surface roughness } \\
\text { was smallest. Whenusing Dy cooling, the } \\
\text { cutting forces were smallest }\end{array}$ & [16] \\
\hline \multirow[t]{2}{*}{ AM alloy } & Minimum surface roughness & Taguchi & $\begin{array}{l}\text { - Cutting velocity } 160 \mathrm{~mm} / \mathrm{min} \text {; } \\
\text { - Feed rate } 0.1 \mathrm{~mm} / \mathrm{rev} \\
\text { - Depth of cut } 0.5 \mathrm{~mm}\end{array}$ & [17] \\
\hline & Minimum cutting force & & $\begin{array}{l}\text { - Cutting velocity } 115 \mathrm{~mm} / \mathrm{min} \text {; } \\
\text { - Feed rate } 0.1 \mathrm{~mm} / \mathrm{rev} \\
\text { - Depth of cut } 0.5 \mathrm{~mm}\end{array}$ & \\
\hline AISI 1045 & Minimum surface roughness & Taguchi & $\begin{array}{l}\text { - Cutting velocity } 200 \mathrm{~m} / \mathrm{min} \text {; } \\
\text { - Feed rate } 0.1 \mathrm{~mm} / \mathrm{rev} \\
\text { - Depth of cut } 0.5 \mathrm{~mm}\end{array}$ & [18] \\
\hline S45C steel & Minimum surface roughness & Taguchi & $\begin{array}{l}\text { - Cutting velocity } 135 \mathrm{~m} / \mathrm{min} \text {; } \\
\text { - Feed rate } 0.08 \mathrm{~mm} / \mathrm{rev} \text {; } \\
\text { - Depth of cut } 1.1 \mathrm{~mm}\end{array}$ & [19] \\
\hline Aluminium & Minimum surface roughness & Taguchi & $\begin{array}{l}\text { - Workpiece speed } 160 \mathrm{rpm} \text {; } \\
\text { - Feed rate } 0.05 \mathrm{~mm} / \mathrm{rev} \\
\text { - Depth of cut } 1.5 \mathrm{~mm}\end{array}$ & [20] \\
\hline Brass & Minimum surface roughness & Taguchi & $\begin{array}{l}\text { - Workpiece speed } 660 \mathrm{rpm} ; \\
\text { - Feed rate } 0.1 \mathrm{~mm} / \mathrm{rev} \\
\text { - Depth of cut } 1.0 \mathrm{~mm}\end{array}$ & \\
\hline Copper & Minimum surface roughness & Taguchi & $\begin{array}{l}\text { - Workpiece speed } 80 \mathrm{rpm} \\
\text { - Feed rate } 0.1 \mathrm{~mm} / \mathrm{rev} \\
\text { - Depth of cut } 1.5 \mathrm{~mm}\end{array}$ & \\
\hline Mild Steel & Minimum surface roughness & Taguchi & $\begin{array}{l}\text { - Cutting velocity } 60 \mathrm{~m} / \mathrm{min} \text {; } \\
\text { - Feed rate } 0.1 \mathrm{~mm} / \mathrm{rev} \\
\text { - Depth of cut } 0.4 \mathrm{~mm}\end{array}$ & [21] \\
\hline EN 354 steel & Minimum surface roughness & Taguchi & $\begin{array}{l}\text { - Cutting velocity } 222 \mathrm{~m} / \mathrm{min} \text {; } \\
\text { - Feed rate } 0.015 \mathrm{~mm} / \mathrm{rev} \\
\text { - Depth of cut } 1.2 \mathrm{~mm}\end{array}$ & [22] \\
\hline $\begin{array}{l}\text { Titanium Alloy Ti- } \\
6 \mathrm{Al}-4 \mathrm{~V}\end{array}$ & Minimum surface roughness & Taguchi & $\begin{array}{l}\text { - Cutting velocity } 125 \mathrm{~m} / \mathrm{min} \text {; } \\
\text { - Feed rate } 0.12 \mathrm{~mm} / \mathrm{rev} \text {; } \\
\text { - Depth of cut } 0.6 \mathrm{~mm}\end{array}$ & [23] \\
\hline
\end{tabular}




\section{Continuation of Table 1}

\begin{tabular}{|c|c|c|c|c|}
\hline 1 & 2 & 3 & 4 & 5 \\
\hline AISI $1020 \mathrm{MS}$ & Minimum surface roughness & Taguchi & $\begin{array}{l}\text { - Workpiece speed } 630 \mathrm{rpm} ; \\
\text { - Feed rate } 0.05 \mathrm{~mm} / \mathrm{rev} \\
\text { - Depth of cut } 1.25 \mathrm{~mm}\end{array}$ & [24] \\
\hline Aluminum-2014 Alloy & Minimum surface roughness & Taguchi & $\begin{array}{l}\text { - Workpiece speed } 1700 \mathrm{rpm} \text {; } \\
\text { - Feed rate } 35 \mathrm{~mm} / \mathrm{min} \\
\text { - Depth of cut } 0.4 \mathrm{~mm}\end{array}$ & [25] \\
\hline AISI 409 steel & Minimum surface roughness & Taguchi & $\begin{array}{l}\text { - Cutting velocity } 400 \mathrm{~m} / \mathrm{min} \text {; } \\
\text { - Feed rate } 0.2 \mathrm{~mm} / \mathrm{rev} \text {; } \\
\text { - Depth of cut } 2.0 \mathrm{~mm}\end{array}$ & [26] \\
\hline P20 steel & Minimum surface roughness & Taguchi & $\begin{array}{l}\text { - Cutting velocity } 120 \mathrm{~m} / \mathrm{min} \text {; } \\
\text { - Feed rate } 0.1 \mathrm{~mm} / \mathrm{rev} \text {; } \\
\text { - Depth of cut } 0.1 \mathrm{~mm}\end{array}$ & [27] \\
\hline \multirow[t]{3}{*}{ DIN 1.2344 steel } & Minimum surface roughness & Taguchi & $\begin{array}{l}\text { - Cutting tool was DCT; } \\
\text { - Cutting velocity } 250 \mathrm{~m} / \mathrm{min} \text {; } \\
\text { - Feed rate } 0.12 \mathrm{~mm} / \mathrm{rev}\end{array}$ & [28] \\
\hline & Minimum tool wear & Taguchi & $\begin{array}{l}\text { - Cutting tool was DCT; } \\
\text { - Cutting velocity } 200 \mathrm{~m} / \mathrm{min} \text {; } \\
\text { - Feed rate } 0.15 \mathrm{~mm} / \mathrm{rev}\end{array}$ & \\
\hline & $\begin{array}{l}\text { - Minimum surface roughness; } \\
\text { - Minimum tool wear }\end{array}$ & Taguchi $+G R A$ & $\begin{array}{l}\text { - Cutting tool was DCT; } \\
\text { - Cutting velocity } 200 \mathrm{~m} / \mathrm{min} \text {; } \\
\text { - Feed rate } 0.12 \mathrm{~mm} / \mathrm{rev}\end{array}$ & \\
\hline $\begin{array}{l}\text { Unidirectional glass } \\
\text { fiber reinforced } \\
\text { plastic (UD-GFRP) } \\
\text { composite }\end{array}$ & $\begin{array}{l}\text { - Minimum surface roughness; } \\
\text { - Maximum MRR. }\end{array}$ & Taguchi $+G R A$ & $\begin{array}{l}\text { - Cutting environment was Cooled; } \\
\text { - Tool nose radius } 0.4 \mathrm{~mm} ; \\
\text { - Tool Rake angle }-6^{\circ} ; \\
\text { - Feed rate } 0.2 \mathrm{~mm} / \mathrm{rev} \\
\text { - Cutting velocity } 159.66 \mathrm{~m} / \mathrm{min} ; \\
\text { - Depth of cut } 1.4 \mathrm{~mm}\end{array}$ & [29] \\
\hline $\begin{array}{l}\text { EN-8, EN-31 and } \\
\text { EN-36 steel }\end{array}$ & Minimum surface roughness & Taguchi+GRA & $\begin{array}{l}\text { - EN-36 material; } \\
\text { - Workpiece speed } 598 \mathrm{rpm} ; \\
\text { - Feed rate } 0.15 \mathrm{~mm} / \mathrm{rev} \\
\text { - Depth of cut. } 5 \mathrm{~mm}\end{array}$ & [30] \\
\hline DIN Ck45 steel & Minimum surface roughness & Taguchi $+G R A$ & $\begin{array}{l}\text { - Cutting velocity } 400 \mathrm{~m} / \mathrm{min} \text {; } \\
\text { - Feed rate } 0.1 \mathrm{~mm} / \mathrm{rev} \\
\text { - Depth of cut } 1.2 \mathrm{~mm}\end{array}$ & {$[31]$} \\
\hline \multirow[t]{2}{*}{ Ti-6Al-4V alloy } & Minimum surface roughness & Taguchi + TOPSIS & $\begin{array}{l}\text { - Cutting velocity } 80 \mathrm{~m} / \mathrm{min} \text {; } \\
\text { - Feed rate } 0.05 \mathrm{~mm} / \mathrm{rev} \text {; } \\
\text { - Depth of cut } 0.1 \mathrm{~mm}\end{array}$ & [32] \\
\hline & Minimum surface roughness & Taguchi $+S A W$ & $\begin{array}{l}\text { - Cutting velocity } 80 \mathrm{~m} / \mathrm{min} \text {; } \\
\text { - Feed rate } 0.05 \mathrm{~mm} / \mathrm{rev} \text {; } \\
\text { - Depth of cut } 0.1 \mathrm{~mm}\end{array}$ & \\
\hline \multirow[t]{2}{*}{ S45C steel } & Minimum surface roughness & Taguchi $+G A$ & $\begin{array}{l}\text { - Cutting velocity } 145.405 \mathrm{~m} / \mathrm{min} \text {; } \\
\text { - Feed rate } 0.0876 \mathrm{~mm} / \mathrm{rev} \text {; } \\
\text { - Depth of cut } 0.6057 \mathrm{~mm}\end{array}$ & [33] \\
\hline & Minimum surface roughness & Taguchi $+P S O$ & $\begin{array}{l}\text { - Cutting velocity } 145 \mathrm{~m} / \mathrm{min} \text {; } \\
\text { - Feed rate } 0.08 \mathrm{~mm} / \mathrm{rev} \\
\text { - Depth of cut } 0.6 \mathrm{~mm}\end{array}$ & \\
\hline
\end{tabular}

From the summary of the reviewed literatures in Table 1, it is clear that many methods and algorithms were applied in optimization of turning processes. However, with different machining material, the obtained values of cutting parameters were different. So, the optimization process should be performed with each specific material. Taguchi method has been successfully applied to optimize the turning processes with different cases. Besides, Taguchi was also successfully combined with one or two of algorithms (GRA, GA, TOPSIS, SAW, PSO, etc.) to optimize the turning processes. 
Up to date, it seems that the combination of Taguchi method and MOORA technique in optimization of the turning processes have not mentioned. Besides, in previous studies, the surface roughness or cutting forces or $M R R$ or two parameters of them were chosen as the output parameters. It also seems a study that was performed in consideration of all five output parameters (Surface roughness, cutting force in $X, Y, Z$ directions, and $M R R$ ) have not been mentioned. EN 10503 steel is a steel type widely used to manufacture the parts in the machine manufacturing. Because this steel has good machinability and low cost. The optimization of turning process of the EN 10503 steel with five above output parameters have been not mentioned and this is a necessary study.

The aim of this research is simultaneously determining the values of four parameters including the tool insert radius, cutting speed, feedrate, and depth of cut to ensure simultaneously output criteria including the minimum value of surface roughness, the minimum values of three cutting force components, and maximum value of MRR when turning the EN 10503 steel. To solve this problem, Taguchi method was applied to design the experimental matrix and MOORA technique was applied to solve the multi-objective optimization problem.

\section{Multi-Objective Optimization using MOORA Technique}

\section{1. Multiple-Criteria Decision Making (MCDM)}

The Multiple-Criteria Decision Making $(M C D M)$ was used to choose the best solution from the set of solutions $A=\left\{A_{1}, A_{2}, \ldots, A_{m}\right\}$ based on the set of criteria $C=\left\{C_{1}, C_{2}, \ldots, C_{n}\right\}$. In which, each crirerion $C_{j}$ is assigned with a weight $w_{j}(j=1,2, \ldots, n)$, so that $S U M\left(w_{j}\right)=1$. A multiple-criteria decision making problem was presented by the matrix $D=\left[d_{i j}\right]_{m \times n}$.

$$
\begin{gathered}
A_{1} \\
A_{2} \\
\vdots \\
A_{3}
\end{gathered}\left[\begin{array}{cccc}
d_{11} & d_{12} & d_{1 n} & d_{1 n} \\
d_{21} & d_{22} & d_{2 n} & d_{2 n} \\
\vdots & \vdots & \vdots & \vdots \\
d_{m 1} & d_{m 2} & d_{m n} & d_{m n}
\end{array}\right],
$$

where $d_{i j} \in R^{+}$with $i=1,2, \ldots, m$ and $j=1,2, \ldots, n$.

In the MOORA technique, the weights were calculated using measurement of Entropy, because this method can get the high accuracy. The steps of the weight calculation process will be performed as following [34, 35]:

Step 1: Calculating the values $p_{i j}$ with $i=1,2, \ldots, m$ and $j=1,2, \ldots, n$ using Eq. (1):

$$
p_{i j}=\frac{d_{i j}}{m+\sum_{i=1}^{m} d_{i j}^{2}} .
$$

Step 2: Calculating the measurement entropy $e_{j}$ of each criterion $C_{j}$ with $j=1,2, \ldots, n$ by Eq. (2):

$$
e_{j}=-\sum_{i=1}^{m}\left[p_{i j} \ln \left(p_{i j}\right)\right]-\left(1-\sum_{i=1}^{m} p_{i j}\right) \cdot \ln \left(1-\sum_{i=1}^{m} p_{i j}\right) \text {. }
$$

Step 3: Calculating the weight $w_{j}$ of each criterion $C_{j}$ with $j=1,2, \ldots, n$ by Eq. (3):

$$
w_{j}=\frac{1-e_{j}}{\sum_{j=1}^{n}\left(1-e_{j}\right)} .
$$

The above equations will be used to maximize the multi-objective optimzation in next part of this paper.

\section{2. MOORA technique}

MOORA technique was introduced the first time in 2004 by Brauers [36]. This multi-objective optimization technique can be successfully applied to solve the complex decision problems 
in the production environment with the together conflicting objectives. The MOORA technique includes the steps as following:

Step 1: Calculating the values $p_{i j}$ with $i=1,2, \ldots, m$ and $j=1,2, \ldots, n$ using Eq. (1).

Step 2: Calculating the measurement entropy $e_{j}$ of each criterion $C_{j}$ with $j=1,2, \ldots, n$ by Eq. (2).

Step 3: Calculating the weight $w_{j}$ of each criterion $C_{j}$ with $j=1,2, \ldots, n$ by Eq. (3). by Eq. (4):

Step 4: Calculating the standardized matrix $\left[X_{i j}\right]_{m \times n}$ with $i=1,2, \ldots, m$ and $j=1,2, \ldots, n$

$$
X=\left[X_{i j}\right]_{m \times n} \text { with } X_{i j}=\frac{d_{i j}}{\sqrt{\sum_{i=1}^{m} d_{i j}^{2}}}
$$

Step 5: Calculating the decision matrix after standardizing with the weight $W=\left[W_{i j}\right]_{m \times n}$ with $i=1,2, . ., m$ and $j=1,2, \ldots, n$ by Eq. (5):

$$
W_{i j}=w_{j} \cdot x_{i j}
$$

Step 6: Calculating $P_{i}$ and $R_{i}$ by Eq. (6) and Eq. (7):

$$
\begin{gathered}
P_{i}=\frac{1}{|B|} \sum_{j \in B} W_{i j}, \\
R_{i}=\frac{1}{|N B|} \sum_{j \in N B} W_{i j},
\end{gathered}
$$

where $B$ and $N B$ are the set of benefit criteria and the set of non-beneficial criteria with $i=1,2, \ldots, m$.

Step 7: Calculating the priority value with $i=1,2, \ldots, m(8)$.

$$
Q_{i}=P_{i}-R_{i}
$$

Step 8: Ranking the solutions $A_{k}>A_{i}$ if $Q_{k}<Q_{i}$ with $i, k=1,2, \ldots, m$.

\section{Material and Experimental Method}

\section{1. Material}

In this study, EN 10503 was used in the external turning process. This is common steel and is often used to manufacture the parts in the machine manufacturing such as mechanical shafts, gears, mechanical levers, etc. The equivalent sign of EN 10503 steel according several standards is described in Table 2.

The specimen is analyzed for spectrum and its chemical composition is introduced in Table $\mathbf{3}$.

Table 2

Equivalent symbols of EN 10503 steel according to several Standards

\begin{tabular}{cccccc}
\hline Germany & United States & Europe & China & Italy & Japan \\
\hline DIN & SAE & EN & BS & UNI & JIS \\
EN 10503 & 1045 & C45 & $060 A 4$ & C45 & S45C
\end{tabular}

Table 3

Chemical composition of EN 10503 steel

\begin{tabular}{ccccccccccc}
\hline Element & $\mathbf{C}$ & $\mathbf{S i}$ & $\mathbf{M n}$ & $\mathbf{C r}$ & $\mathbf{N i}$ & $\mathbf{M o}$ & $\mathbf{V}$ & $\mathbf{T i}$ & $\mathbf{B}$ & $\mathbf{C u}$ \\
\hline$\%$ & 0.44 & 0.23 & 0.65 & 0.15 & 0.15 & 0.04 & 0.01 & 0.001 & 0.0004 & 0.21
\end{tabular}


The properties of EN 10503 steel are listed in Table 4.

Table 4

Properties of EN 10503 steel

\begin{tabular}{|c|c|c|c|}
\hline Youngs module (GPa) & Poisson's ratio & Shear module (GPa) & Density $\left(\mathrm{kg} / \mathrm{m}^{3}\right)$ \\
\hline 210 & 0.3 & 80 & 7800 \\
\hline $\begin{array}{c}\text { Average CTE } \\
20-300{ }^{\circ} \mathrm{C}\left(\mu \mathrm{m} / \mathrm{m} \cdot{ }^{\circ} \mathrm{K}\right)\end{array}$ & $\begin{array}{l}\text { Specific heat capacity } \\
50 / 100{ }^{\circ} \mathrm{C}(\mathrm{J} / \mathrm{kg} \cdot \mathrm{K})\end{array}$ & $\begin{array}{c}\text { Thermal conductivity } \\
\text { Ambient temperature }\left(\mathrm{W} / \mathrm{m} \cdot{ }^{\circ} \mathrm{K}\right)\end{array}$ & $\begin{array}{l}\text { Electrical resistivity Ambient } \\
\text { temperature }(\mu \Omega \mathrm{m})\end{array}$ \\
\hline 12 & $460-480$ & $40-45$ & $0.20-0.25$ \\
\hline
\end{tabular}

The length and diameter of workpiece were $300 \mathrm{~mm}$ and $27.5 \mathrm{~mm}$, respectively, as shown in Fig. 1.

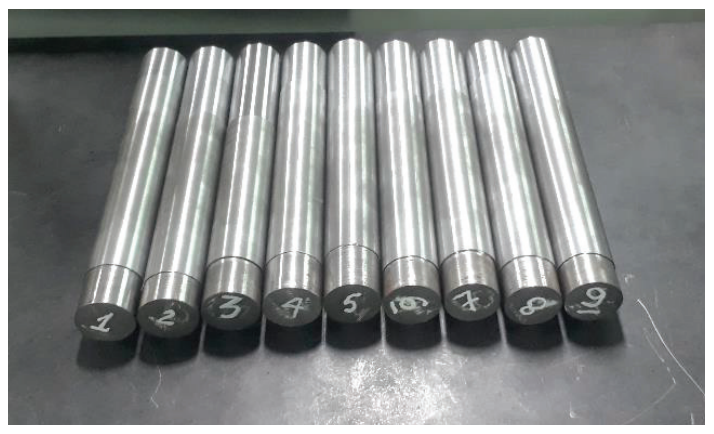

Fig. 1. Experimental workpieces

\section{2. Experimental Machine and Cutter}

The manual lathe (FEL-1440GMW, MAGNUM-CUT, Taiwan) was used to conduct the experiments. Three insert types (Lungaloy, Japan) with the nose radius of $0.4 \mathrm{~mm}, 0.6 \mathrm{~mm}$, and $1.2 \mathrm{~mm}$ were used in the experimental process. The cutting inserts are coated with titanium.

\section{3. Experimental Matrix}

In this study, the Taguchi method was used to design the experimental matrix. Four input parameters were insert nose radius $(r)$, cutting speed $(n)$, feed rate $(f)$, and depth of cut $\left(a_{p}\right)$. Three selected values of the insert nose radius are those commonly used in turning processes. The values for cutting speed, feedrate, and depth of cut are chosen based on the cutting tool manufacturer's recommendation for turning steel in general and EN 10503 steel in particular and also based on the adjustment ability of these parameters of the experimental machine. These parameters were selected as the controllable factors, and their levels were presented in Table 5. The orthogonal array $\left(L_{9}\right)$ with 9 experiments was selected to design the experimental matrix as listed in Table 6.

Table 5

Input parameters and their levels

\begin{tabular}{cccccc}
\hline \multirow{2}{*}{ Parameters } & Symbol & Unit & \multicolumn{3}{c}{ Value at the level } \\
\cline { 4 - 6 } & & & $\mathbf{1}$ & $\mathbf{2}$ & $\mathbf{3}$ \\
\hline Insert nose radius & $r$ & $\mathrm{~mm}$ & 0.4 & 0.6 & 1.2 \\
Cutting speed & $n$ & $\mathrm{rev} / \mathrm{min}$ & 460 & 650 & 910 \\
Feed rate & $f$ & $\mathrm{~mm} / \mathrm{rev}$ & 0.08 & 0.194 & 0.302 \\
Depth of cut & $a_{p}$ & $\mathrm{~mm}$ & 0.15 & 0.30 & 0.45
\end{tabular}


Table 6

Experimental Matrix

\begin{tabular}{lllll}
\hline No. & \multicolumn{3}{c}{ Coded value } & \\
\cline { 2 - 5 } & $\boldsymbol{r}$ & $\boldsymbol{n}$ & $\boldsymbol{f}$ & $\boldsymbol{a}_{\boldsymbol{p}}$ \\
\hline 1 & 1 & 1 & 1 & 1 \\
2 & 1 & 2 & 2 & 2 \\
3 & 1 & 3 & 3 & 3 \\
4 & 2 & 1 & 2 & 3 \\
5 & 2 & 2 & 3 & 1 \\
6 & 2 & 3 & 1 & 2 \\
7 & 3 & 1 & 3 & 2 \\
8 & 3 & 2 & 1 & 3 \\
9 & 3 & 3 & 2
\end{tabular}

According to this experimental matrix form, there will be 9 experiments to be performed. At each experiment, the five input parameters will be changed simultaneously.

\section{4. Measurement system and Calculation of MRR}

\section{4. 1. Surface roughness measurement system}

The MITUTOYO-Surftest SJ-210 surface roughness tester was used to measure the surface roughness of the machined parts. The evaluation length was fixed at $0.8 \mathrm{~mm}$ (The standard length) as described in Fig. 2.

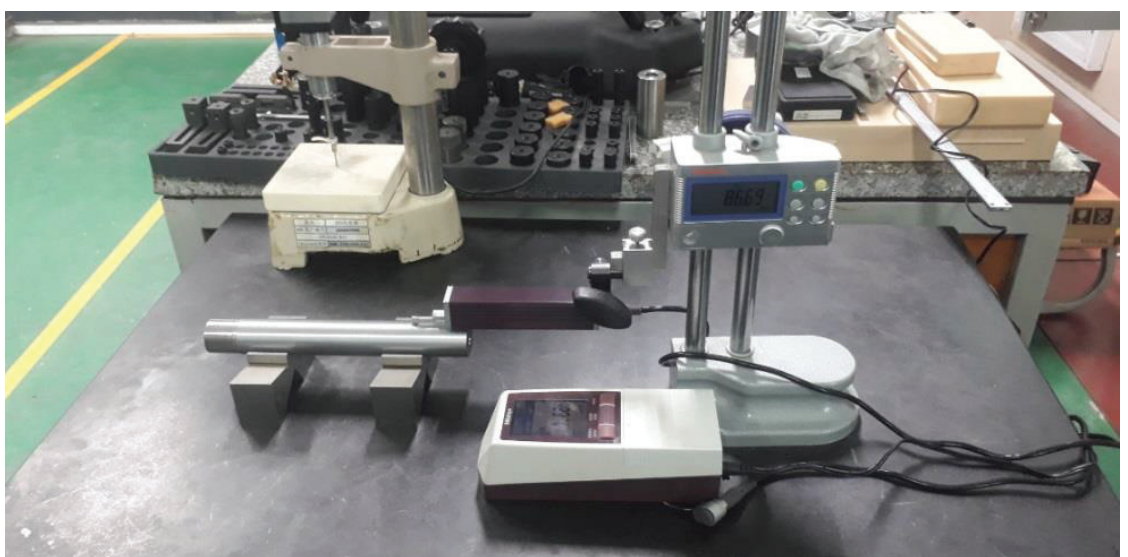

Fig. 2. Surface roughness measurement setup

The surface roughness was measured perpendicular to the cutting velocity direction and repeated three times following three repeated times of each cutting test. The average value of surface roughness of three measurement consecutive times was used for analysis and evaluation of surface roughness.

\section{4. 2. Cutting force measurement system}

Cutting forces in three directions $(X, Y$, and $Z$ ) were measured using a dynamometer (Kistler Type 9139AA: Force Ranges: $(-3 \mathrm{KN} \div 3 \mathrm{KN})$, a data processing box, and a PC with DynoWare software as described in Fig. 3.

The data-processing devices were connected to the computer and they processed the results of the measurement of the component forces by the dynamometer. The value of the forces at each experiment is the average during the machining operation. 


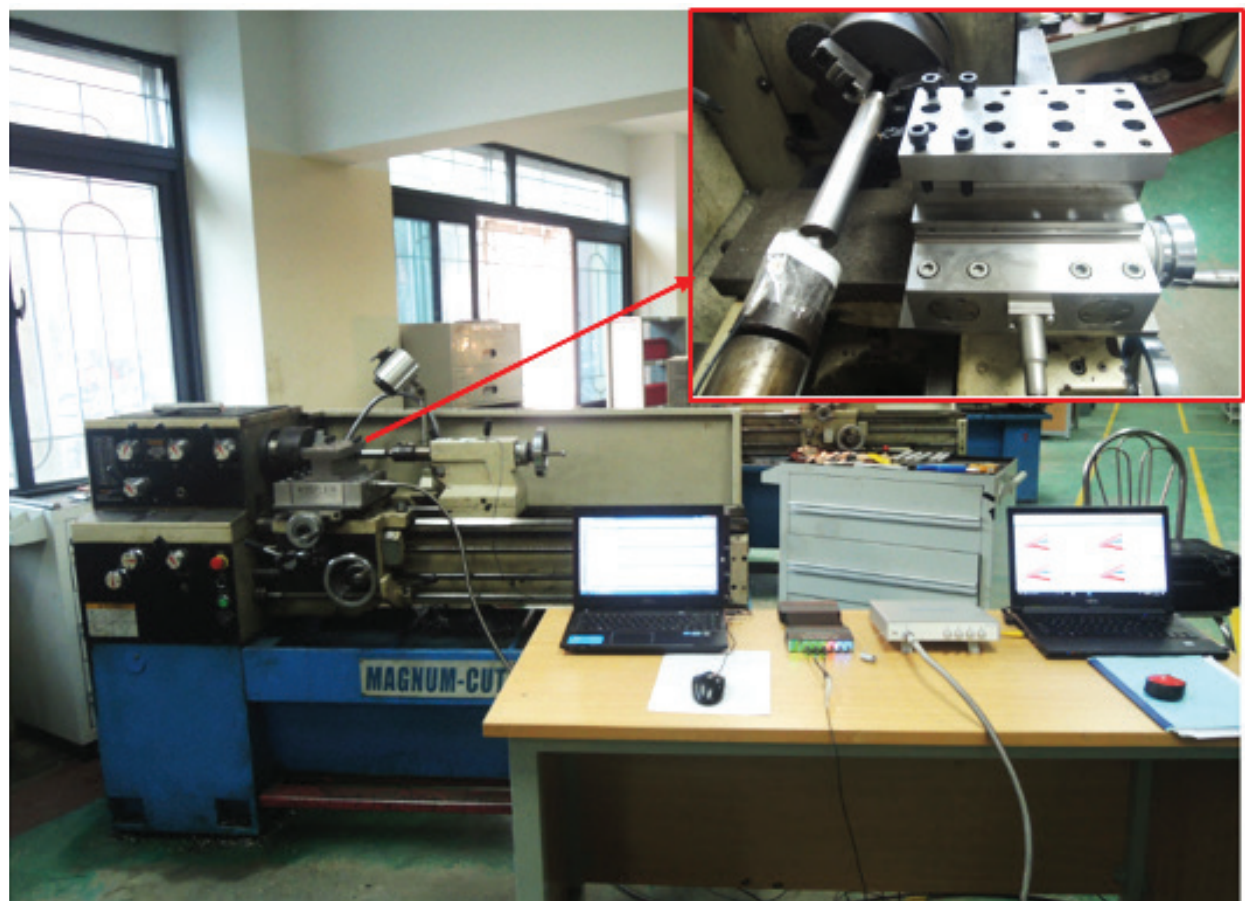

Fig. 3. Cutting force measurement setup

\section{4. 3. Calculation of Material Removal Rate}

The material removal rate $(M R R)$ was calculated by Eq (9).

$$
M R R=\frac{1}{60} \cdot n \cdot \pi \cdot d \cdot f \cdot a_{p}\left(\mathrm{~mm}^{3} / \mathrm{s}\right),
$$

where $n$ is cutting speed (rev/min); $d$ is diameter of workpiece $(\mathrm{mm}) ; f$ is feed rate $(\mathrm{mm} / \mathrm{rev}) ; a_{p}$ is depth of cut (mm).

\section{Results and Discussion}

\section{1. Experiment results}

The experimental results were listed in Table 7. The experimental results in this table show that it is difficult to determine which of the experiment in 9 performed experiments have simultaneously the minimum value of surface roughness, minimum values of all three cutting force components, and the maximum of MRR. This is explained as follows:

Table 7

Experimental Results

\begin{tabular}{cccccc}
\hline No. & $\boldsymbol{R} \boldsymbol{a}(\boldsymbol{\mu m})$ & $\boldsymbol{F x}(\mathbf{N})$ & $\boldsymbol{F y}(\mathbf{N})$ & $\boldsymbol{F z}(\mathbf{N})$ & $\boldsymbol{M R R}\left(\mathbf{m m}^{\mathbf{3}} / \mathbf{s}\right)$ \\
\hline 1 & 0.840 & 85.274 & 24.980 & 107.440 & 7.948 \\
2 & 0.605 & 166.234 & 47.542 & 230.321 & 54.471 \\
3 & 0.644 & 563.730 & 153.285 & 965.227 & 178.071 \\
4 & 1.122 & 219.203 & 64.022 & 335.737 & 57.823 \\
5 & 0.669 & 152.266 & 38.583 & 191.541 & 42.398 \\
6 & 0.643 & 175.323 & 44.147 & 211.683 & 31.447 \\
7 & 0.621 & 191.084 & 51.727 & 300.162 & 60.009 \\
8 & 0.729 & 212.926 & 59.117 & 307.879 & 33.694 \\
9 & 0.675 & 124.969 & 40.545 & 164.206 & 38.130
\end{tabular}


With the results in Table 7, for example, in the experiment 2, the surface roughness was the smallest value (equal to $0.605 \mu \mathrm{m}$ ), but in this experiment, the values of all three cutting force components were not the smallest values. Besides, $M R R$ in this experiment was also not the maximum value. Another example is experiment 3, in this experiment, $M R R$ was the largest value, but also in this experiment, the value of the cutting force components also were the maximum values. Besides, the surface roughness was not the smallest in this experiment.

From above analysis showed that, it is not possible to choose one experiment from 9 performed experiments to ensure simultaneously the minimum value of surface roughness, the minimum values of cutting force components, and the maximum value of $M R R$. So that, it is necessary to solve the multi-objective optimization problem to determine the experiment with small surface roughness, small cutting force components, and large $M R R$. This issue will be presented in next section.

\section{2. Multi-Objective Optimization of Turning Process using MOORA Technique}

To facilitate for the using of the mathematical symbols when optimizing according to MOORA techniques, the surface roughness, cutting force in $X$ direction, cutting force in $Y$ direction, cutting force in $Z$ direction, and $M R R$ criteria were set as $C_{1}, C_{2}, C_{3}, C_{4}$, and $C_{5}$ as presented in Table 8.

Table 8

The evaluation criteria of the turning process

\begin{tabular}{cccccc}
\hline No. & $\boldsymbol{C}_{\mathbf{1}}$ & $\boldsymbol{C}_{\mathbf{2}}$ & $\boldsymbol{C}_{\mathbf{3}}$ & $\boldsymbol{C}_{\mathbf{4}}$ & $\boldsymbol{C}_{\mathbf{5}}$ \\
\hline$A_{1}$ & 0.840 & 85.274 & 24.980 & 107.440 & 7.948 \\
$A_{2}$ & 0.605 & 166.234 & 47.542 & 230.321 & 54.471 \\
$A_{3}$ & 0.644 & 563.730 & 153.285 & 965.227 & 178.071 \\
$A_{4}$ & 1.122 & 219.203 & 64.022 & 335.737 & 57.823 \\
$A_{5}$ & 0.669 & 152.266 & 38.583 & 191.541 & 42.398 \\
$A_{6}$ & 0.643 & 175.323 & 44.147 & 211.683 & 31.447 \\
$A_{7}$ & 0.621 & 191.084 & 51.727 & 300.162 & 60.009 \\
$A_{8}$ & 0.729 & 212.926 & 59.117 & 307.879 & 33.694 \\
$A_{9}$ & 0.675 & 124.969 & 40.545 & 164.206 & 38.130
\end{tabular}

From the data in Table 3, MOORA technique applied to calculate the values according to the following steps:

Step 1: Using Eq. (1), the values $p_{i j}$ were calculated and listed in Table 9.

Table 9

The values of $p_{i j}$

\begin{tabular}{cccccc}
\hline \multirow{2}{*}{ No. } & \multicolumn{5}{c}{$\boldsymbol{p}_{\boldsymbol{i j}}$} \\
\cline { 2 - 6 } & $\boldsymbol{C}_{\mathbf{1}}$ & $\boldsymbol{C}_{\mathbf{2}}$ & $\boldsymbol{C}_{\mathbf{3}}$ & $\boldsymbol{C}_{\mathbf{4}}$ & $\boldsymbol{C}_{\mathbf{5}}$ \\
\hline$A_{1}$ & 0.084177 & 0.000154 & 0.000599 & 0.000076616 & 0.000169 \\
$A_{2}$ & 0.060628 & 0.000301 & 0.001139 & 0.000164242 & 0.001157 \\
$A_{3}$ & 0.064536 & 0.001021 & 0.003673 & 0.000688304 & 0.003784 \\
$A_{4}$ & 0.112437 & 0.000397 & 0.001534 & 0.000239414 & 0.001229 \\
$A_{5}$ & 0.067041 & 0.000276 & 0.000924 & 0.000136588 & 0.000901 \\
$A_{6}$ & 0.064436 & 0.000318 & 0.001058 & 0.000150951 & 0.000668 \\
$A_{7}$ & 0.062231 & 0.000346 & 0.001239 & 0.000214046 & 0.001275 \\
$A_{8}$ & 0.073054 & 0.000386 & 0.001416 & 0.000219549 & 0.000716 \\
$A_{9}$ & 0.067642 & 0.000226 & 0.000971 & 0.000117095 & 0.00081
\end{tabular}

Step 2: Using Eq. (2), the values $e_{j}$ of each criterion $C_{j}$ were calculated and listed in Table 10.

Step 3: Using Eq. (3), the values $w_{j}$ of each criterion $C_{j}$ were calculated and listed in Table 10. 
Table 10

Weight of the criteria

\begin{tabular}{cccccc}
\hline Parameter & $\boldsymbol{C}_{\mathbf{1}}$ & $\boldsymbol{C}_{\mathbf{2}}$ & $\boldsymbol{C}_{\mathbf{3}}$ & $\boldsymbol{C}_{\mathbf{4}}$ & $\boldsymbol{C}_{\mathbf{5}}$ \\
\hline Entropy & 2.07193 & 0.02986 & 0.09320 & 0.01843 & 0.07993 \\
Weight & -0.39604 & 0.35843 & 0.33503 & 0.36265 & 0.33993
\end{tabular}

Step 4: Using Eq. (4), the standardized matrix $X=\left[X_{i j}\right]_{m \times n}$ was calculated and listed in Table 11.

Step 5: Using Eq. (5), the decision matrix $W$ after standardizing with the weight was calculated and listed in Table 12.

Step 6: Using Eq. (6) and Eq. (7), the values $P_{i}$ and $Q_{i}$ were calculated and listed in Table 13

Step 7: Using Eq. (8), the values $Q_{i}$ were calculated and listed in Table 13.

Table 11

Standardized matrix

\begin{tabular}{cccccc}
\hline No. & $\boldsymbol{C}_{\mathbf{1}}$ & $\boldsymbol{C}_{\mathbf{2}}$ & $\boldsymbol{C}_{\mathbf{3}}$ & $\boldsymbol{C}_{\mathbf{4}}$ & $\boldsymbol{C}_{\mathbf{5}}$ \\
\hline$A_{1}$ & 0.37645 & 0.11476 & 0.12228 & 0.09073 & 0.03664 \\
$A_{2}$ & 0.27114 & 0.22372 & 0.23273 & 0.19450 & 0.25110 \\
$A_{3}$ & 0.28861 & 0.75866 & 0.75036 & 0.81509 & 0.82086 \\
$A_{4}$ & 0.50283 & 0.29500 & 0.31340 & 0.28351 & 0.26655 \\
$A_{5}$ & 0.29982 & 0.20492 & 0.18887 & 0.16175 & 0.19544 \\
$A_{6}$ & 0.28817 & 0.23595 & 0.21611 & 0.17876 & 0.14496 \\
$A_{7}$ & 0.27831 & 0.25716 & 0.25321 & 0.25347 & 0.27662 \\
$A_{8}$ & 0.32671 & 0.28655 & 0.28939 & 0.25999 & 0.15532 \\
$A_{9}$ & 0.30251 & 0.16818 & 0.19848 & 0.13866 & 0.17577
\end{tabular}

Table 12

Combination of Standardized matrix and Weight

\begin{tabular}{cccccc}
\hline No. & $\boldsymbol{C}_{\mathbf{1}}$ & $\boldsymbol{C}_{\mathbf{2}}$ & $\boldsymbol{C}_{\mathbf{3}}$ & $\boldsymbol{C}_{\mathbf{4}}$ & $\boldsymbol{C}_{\mathbf{5}}$ \\
\hline$A_{1}$ & -0.33267 & 30.56476 & 8.36905 & 38.96312 & 2.70176 \\
$A_{2}$ & -0.23960 & 59.58325 & 15.92800 & 83.52591 & 18.51633 \\
$A_{3}$ & -0.25505 & 202.05774 & 51.35507 & 350.03957 & 60.53168 \\
$A_{4}$ & -0.44436 & 78.56893 & 21.44929 & 121.75502 & 19.65577 \\
$A_{5}$ & -0.26495 & 54.57670 & 12.92646 & 69.46234 & 14.41235 \\
$A_{6}$ & -0.25465 & 62.84102 & 14.79057 & 76.76684 & 10.68978 \\
$A_{7}$ & -0.24594 & 68.49024 & 17.33010 & 108.85375 & 20.39886 \\
$A_{8}$ & -0.28871 & 76.31907 & 19.80597 & 111.65232 & 11.45360 \\
$A_{9}$ & -0.26733 & 44.79264 & 13.58379 & 59.54931 & 12.96153
\end{tabular}

Table 13

Calculated results of $P_{i}, R_{i}, Q_{i}$ and the ranked results

\begin{tabular}{ccccc}
\hline No. & $\boldsymbol{P}_{\boldsymbol{i}}$ & $\boldsymbol{R}_{\boldsymbol{i}}$ & $\boldsymbol{Q}_{\boldsymbol{i}}$ & Ranking \\
\hline$A_{1}$ & 19.39106 & 2.70176 & 16.68930 & 2 \\
$A_{2}$ & 39.69939 & 18.51633 & 21.18306 & 4 \\
$A_{3}$ & 150.79933 & 60.53168 & 90.26766 & 9 \\
$A_{4}$ & 55.33222 & 19.65577 & 35.67645 & 7 \\
$A_{5}$ & 34.17514 & 14.41235 & 19.76279 & 3 \\
$A_{6}$ & 38.53594 & 10.68978 & 27.84617 & 5 \\
$A_{7}$ & 48.60704 & 20.39886 & 28.20818 & 6 \\
$A_{8}$ & 51.87216 & 11.45360 & 40.41856 & 8 \\
$A_{9}$ & 29.41460 & 12.96153 & 16.45307 & 1
\end{tabular}


The calculated results from Table 13 showed that the solution $A_{9}$ was the best solution in 9 solutions because this is the solution having the smallest value of $Q_{i}$. If considering only the surface roughness criterion or only the cutting force components or only $M R R, A_{9}$ is not the best solution (Table 7). However, when simultaneously considering five parameters including the surface roughness, three cutting force components, and $M R R$, the solution $A_{9}$ was the best solution. In this experiment, the surface roughness was smaller than that ones in Experiments 1, 4, and 8. The cutting force components in $x$ and $z$ directions both have very small values and these cutting force components are at position number 2 (these cutting force component values were only larger than that ones in experiment 1); the force component in $Y$ direction also has very small value and it was ranked at position number 3 (this cutting force component value was only larger than that ones in experiment 1 and 5), in this experiment, $M R R$ was ranked at position number 6 (this $M R R$ value was smaller than ones in experiment $2,3,4,5$, and 7). So, these optimal values of insert nose radius, cutting velocity, feed rate, and cutting depth were $1.2 \mathrm{~mm}, 76.82 \mathrm{~m} / \mathrm{min}, 0.194 \mathrm{~mm} / \mathrm{rev}$, and $0.15 \mathrm{~mm}$, respectively. Using these optimal values of the input parameters, the surface roughness, cutting force amplitudes in $X, Y, Z$ directions, and material removal rate were $0.675 \mu \mathrm{m}, 124.969 \mathrm{~N}$, $40.545 \mathrm{~N}, 164.206 \mathrm{~N}$, and $38.130 \mathrm{~mm}^{3} / \mathrm{s}$, respectively. The proposed method in this study can be applied to improve the quality and effectiveness of turning processes by improving the surface quality, reducing the cutting force amplitudes, and increasing the material removal rate.

In this study, only four input parameters are considered, have not considered the material and shape of the cutting tool (insert). Besides, other factors of the turning process affect the output parameters such as workpiece material, workpiece hardness, cooling lubrication conditions, etc. also have not considered in this study. These are issues that need to be done in the next research to evaluate the turning process in a more comprehensive way.

\section{Conclusions}

In this study, Taguchi method and MOORA technique were applied to solve the multi-objective optimization problem for external turning process of EN 10503 steel. The conclusions of this study were drawn as following:

- Taguchi method and MOORA techniques were successfully used to solve the multi-objective optimization problem for external turning process of EN 10503 steel.

- These optimal values of the insert nose radius, cutting velocity, feed rate, and cutting depth were $1.2 \mathrm{~mm}, 76.82 \mathrm{~m} / \mathrm{min}, 0.194 \mathrm{~mm} / \mathrm{rev}$, and $0.15 \mathrm{~mm}$, respectively. Using these optimal values of the input parameters, the surface roughness, cutting force amplitudes in $X, Y, Z$ directions, and material removal rate were $0.675 \mu \mathrm{m}, 124.969 \mathrm{~N}, 40.545 \mathrm{~N}, 164.206 \mathrm{~N}$, and $38.130 \mathrm{~mm}^{3} / \mathrm{s}$, respectively.

- The proposed method in this study can be applied to improve the quality and effectiveness of turning processes by improving the surface quality, reducing the cutting force amplitudes, and increasing the material removal rate.

\section{Acknowledgements}

The authors thank Faculty of Mechanical Engineering, Hanoi University of Industry for the support during the implementation of this research.

\section{References}

[1] Do Duc, T., Nguyen Ba, N., Nguyen Van, C., Nguyen Nhu, T., Hoang Tien, D. (2020). Surface Roughness Prediction in CNC Hole Turning of 3X13 Steel using Support Vector Machine Algorithm. Tribology in Industry, 42 (4), 597-607. doi: https:// doi.org/10.24874/ti.940.08.20.11

[2] Makadia, A. J., Nanavati, J. I. (2013). Optimisation of machining parameters for turning operations based on response surface methodology. Measurement, 46 (4), 1521-1529. doi: https://doi.org/10.1016/j.measurement.2012.11.026

[3] Frifita, W., Ben Salem, S., Haddad, A., Yallese, M. A. (2020). Optimization of machining parameters in turning of Inconel 718 Nickel-base super alloy. Mechanics \& Industry, 21 (2), 203. doi: https://oi.org/10.1051/meca/2020001

[4] Chopra, A., Singh, L. (2017). Optimization of Cutting Parameters in Turning Process for Inconel 718 using RSM. International Journal for Scientific Research \& Development, 5 (7), 803-807. 
[5] Bhuiyan, T. H., Ahmed, I. (2014). Optimization of Cutting Parameters in Turning Process. SAE International Journal of Materials and Manufacturing, 7 (1), 233-239. doi: https://doi.org/10.4271/2014-01-9097

[6] Poornima, Sukumar (2012). Optimization of machining parameters in CNC turning of martensitic stainless steel using RSM and GA. International Journal of Modern Engineering Research, 2 (2), 539-542.

[7] Ganesh, M., Kumar, M. U., Kumar, V., Kumar, B. S. (2014). Optimization of cutting parameters in turning of EN 8 steel using response surface method and genetic algorithm. International jounrnal of mechanical engineering and robotics research, 3 (2), 75-86.

[8] Pourmostaghimi, V., Zadshakoyan, M., Badamchizadeh, M. A. (2020). Intelligent model-based optimization of cutting parameters for high quality turning of hardened AISI D2. Artificial Intelligence for Engineering Design, Analysis and Manufacturing, 34 (3), 421-429. doi: https://doi.org/10.1017/s089006041900043x

[9] Qiao, Y., Ai, X., Liu, Z. Q. (2010). Selection of Tool Materials and Cutting Parameters Optimization for Turning NickelBased Powder Metallurgy Superalloy. Advanced Materials Research, 154-155, 708-711. doi: https://doi.org/10.4028/ www.scientific.net/amr.154-155.708

[10] Serra, R., Chibane, H., Duchosal, A. (2018). Multi-objective optimization of cutting parameters for turning AISI 52100 hardened steel. The International Journal of Advanced Manufacturing Technology, 99 (5-8), 2025-2034. doi: https://doi.org/10.1007/ s00170-018-2373-3

[11] Sahu, P. K., Sahu, N. K., Dubey, A. (2017). Optimization of cutting parameters by turning operation in lathe machine. International Journal of Mechanical and Production Engineering, 5 (11), 46-51.

[12] Lazarević, D., Madić, M., Janković, P., Lazarević, A. (2012). Cutting Parameters Optimization for Surface Roughness in Turning Operation of Polyethylene (PE) Using Taguchi Method. Tribology in Industry, 34 (2), 68-73.

[13] Upletawala, M. A. I., Katratwar, T. (2016). Optimization of Cutting Parameters for Turning Operation on Thermoplastic Polymer-Delrin 500AL. International Journal of Innovative Research in Science, Engineering and Technology, 5 (8), $15545-15553$.

[14] Banerjee, S., Kundu, S., Choudhury, S., Chatterjee, A. (2017). Process parameter optimization in lathe turning operation to improve the surface roughness and reduce the cutting force using Taguchi method. International journal of innovations in engineering research and technology, 4 (8), 1-8.

[15] Babu, D. M., Kumar, M. S., Vishnuu, J. (2012). Optimization of cutting parameters for CNC turned parts using Taguchi's technique. Annals of faculty engineering Hunedoara - International journal of engineering, 10 (3), 493-496.

[16] Basmaci, G. (2018). Optimization of Machining Parameters for the Turning Process of AISI 316 L Stainless Steel and Taguchi Design. Acta Physica Polonica A, 134 (1), 260-264. doi: https://doi.org/10.12693/aphyspola.134.260

[17] Dutta, S., Kumar Reddy Narala, S. (2021). Optimizing turning parameters in the machining of AM alloy using Taguchi methodology. Measurement, 169, 108340. doi: https://doi.org/10.1016/j.measurement.2020.108340

[18] Chomsamutr, K., Jongprasithporn, S. (2010). The cutting parameters design for product quality improvement in turning operations: Optimization and validation with Taguchi method. The 40th International Conference on Computers \& Indutrial Engineering. doi: https://doi.org/10.1109/iccie.2010.5668340

[19] Yang, W. H., Tarng, Y. S. (1998). Design optimization of cutting parameters for turning operations based on the Taguchi method. Journal of Materials Processing Technology, 84 (1-3), 122-129. doi: https://doi.org/10.1016/s0924-0136(98)00079-x

[20] Patod, S. K., Sharma, D. S. (2019). Optimization of CNC Turning Cutting Parameter for Geometrical Dimensional Accuracy with Surface roughness on the non-ferrous Material Applying Taguchi Technique. International Journal of Engineering Trends and Technology, 67 (12), 56-66. doi: https://doi.org/10.14445/22315381/ijett-v67i12p210

[21] Saraswat, N., Yadav, A., Kumar, A., Srivastava, B. P. (2014). Optimization of Cutting Parameters in Turning Operation of Mild Steel. International Review of Applied Engineering Research, 4 (3), 251-256.

[22] Kajal, S., Yadav, S. (2015). Optimization of CNC Turning Parameters for Surface Roughness on EN 354 Steel using Taguchi Method. Journal of Material Science and Mechanical Engineering, 2 (10), 54-57.

[23] Shahebrahimi, S. P., Dadvand, A. (2013). Optimization of Cutting Parameters for Turning Operation of Titanium Alloy Ti-6Al-4V Material Workpiece Using the Taguchi Method. Advanced Materials Research, 685, 57-62. doi: https://oi.org/ 10.4028/www.scientific.net/amr.685.57

[24] Sonowal, D., Sarma, D., Barua, P. B., Nath, T. (2017). Taguchi Optimization of Cutting Parameters in Turning AISI 1020 MS with M2 HSS Tool. IOP Conference Series: Materials Science and Engineering, 225, 012186. doi: https://oi.org/10.1088/ $1757-899 \mathrm{x} / 225 / 1 / 012186$

[25] Aswal, A., Jha, A., Tiwari, A., Modi, Y. (2019). CNC Turning Parameter Optimization for Surface Roughness of Aluminium-2014 Alloy Using Taguchi Methodology. Journal Européen Des Systèmes Automatisés, 52 (4), 387-390. doi: https:// doi.org/10.18280/jesa. 520408 
[26] Özdemir, M. (2019). Optimization with Taguchi Method of Influences on Surface Roughness of Cutting Parameters in CNC Turning Processing. Mechanics, 25 (5), 397-405. doi: https://doi.org/10.5755/j01.mech.25.5.23005

[27] Qureshi, A., Sorte, M., Teli, S. N. (2015). Optimization of Cutting parameters for Surface roughness in CNC turning of P20 steel. International Journal of Scientific \& Engineering Research, 6 (12), 133-138.

[28] Nas, E., Altan Özbek, N. (2019). Optimization of the machining parameters in turning of hardened hot work tool steel using cryogenically treated tools. Surface Review and Letters, 27 (05), 1950177. doi: https://doi.org/10.1142/s0218625x19501774

[29] Gupta, M., Kumar, S. (2013). Multi-objective optimization of cutting parameters in turning using grey relational analysis. International Journal of Industrial Engineering Computations, 4 (4), 547-558. doi: https://oi.org/10.5267/j.ijiec.2013.06.001

[30] Madhavi, S., Sreeramulu, D., Venkatesh, M. (2016). Optimization of turning process parameters by using grey-Taguchi. International Journal of Engineering, Science and Technology, 7 (4), 1. doi: https://doi.org/10.4314/ijest.v7i4.1

[31] Puh, F., Jurkovic, Z., Perinic, M., Brezocnik, M., Buljan, S. (2016). Optimization of machining parameters for turning operation with multiple quality characteristics using Grey relational analysis. Tehnički vjesnik, 23 (2), 377-382. doi: https:// doi.org/10.17559/tv-20150526131717

[32] Singh, R., Dureja, J. S., Dogra, M., Randhawa, J. S. (2019). Optimization of machining parameters under MQL turning of Ti-6Al-4V alloy with textured tool using multi-attribute decision-making methods. World Journal of Engineering, 16 (5), 648-659. doi: https://doi.org/10.1108/wje-06-2019-0170

[33] Mallampati, M., Das, V. C. (2012). Optimization Of Cutting Parameters As Speed, Feed \& Depth Of Cut Based On Surface Roughness In Turning Process Using Genetic Algorithm (Ga) And Particle Swarm Optimization (Pso). International Journal of Engineering Research \& Technology, 1 (7), 1-11.

[34] Zavadskas, E. K., Antucheviciene, J., Chatterjee, P. (Eds.) (2019). Multiple-Criteria Decision-Making (MCDM) Techniques for Business Processes Information Management. MPDI, 320. doi: https://doi.org/10.3390/books978-3-03897-643-1

[35] Triantaphyllou, E. (2000). Multi-criteria Decision Making Methods: A Comparative Study. Springer, 290. doi: https://doi.org/ 10.1007/978-1-4757-3157-6

[36] Brauers, W. K. (2004). Optimization methods for a stakeholder society. A revolution in economic thinking by multi-objective optimization. Springer, 342. doi: https://doi.org/10.1007/978-1-4419-9178-2

Received date 28.01.2021

Accepted date 07.03.2021

Published date 31.03.2021
(C) The Author(s) 2021

This is an open access article under the CC BY license (http://creativecommons.org/licenses/by/4.0).

How to cite: Trung, D. D., Nguyen, N.-T., Duc, D. V. (2021). Study on multi-objective optimization of the turning process of EN 10503 steel by combination of taguchi method and moora technique. EUREKA: Physics and Engineering, 2, 52-65. doi: https:// doi.org/10.21303/2461-4262.2021.001414 